\title{
Ni-P AS A NEW MATERIAL FOR THICK FILM TECHNOLOGY
}

\author{
I. BARYCKA, B. HOEODNIK and A. MISIUK \\ Institute of Electron Technology, Technical University of Wroctaw, 50-370 Wroctaw, Poland
}

(Received January 16, 1980)

\begin{abstract}
The product of nickel ions reduction in buffered solution by hypophosphite, known as Ni-P, was examined as a potentially useful material for thick film technology. This material, when mixed with glass oxidizes if heated above $450^{\circ} \mathrm{C}$ in an air atmosphere. For this reason we investigated the possibility of using an additive to stabilize the Ni-P against oxidation. We found that $\mathrm{B}_{2} \mathrm{O}_{3}$ as an additive showed itself to be most satisfactory. A detailed investigation of the phase relations in heated Ni-P, Ni-P-glass and Ni-P-glass- $\mathrm{B}_{2} \mathrm{O}_{3}$ compositions was performed. The inks prepared so far from the mix ture of Ni-P-glass- $\mathrm{B}_{2} \mathrm{O}_{3}$ can only be used in thick film technology for conductor layer production $\left(R_{\square} \sim 0.1 \Omega\right)$.

The most satisfying and practically useful characteristics were obtained for inks produced from solid components containing 45 to $80 \mathrm{wt} \% \mathrm{Ni}-\mathrm{P}$ and about $10 \mathrm{wt} \% \mathrm{~B}_{2} \mathrm{O}_{3}$.
\end{abstract}

\section{INTRODUCTION}

As a result of growing demand for passive electronic elements an intensive search for cheaper, non-noble materials to be used as conductors and resistors is being undertaken. Conducting inks containing $\mathrm{Cu}, \mathrm{Al}$ and $\mathrm{Ni}$ have been produced recently. Based on the fact, that on the one hand powdered $\mathrm{Ni}$ is one of the major components of the cheap conducting inks and, on the other hand, that the chemically reduced nickel containing phosphorus, known as Ni-P, shows good resistive properties in thin film form, ${ }^{1,2}$ some investigations on the usefulness of Ni-P in the production of passive electronic elements by thick film technology have been performed.

The authors realized that there are some considerable differences between thick and thin film technologies and hence the repetition of thin film Ni-P properties in the thick film form is rather impossible. In particular the firing treatment usually above $500^{\circ} \mathrm{C}$, and the presence of the additives, e.g. glass, can influence the Ni-P properties. However, Ni-P seemed to us to be a promising material, so we attempted to investigate the usefulness of $\mathrm{Ni}-\mathrm{P}$ in the production of passive elements by thick film technology.

A common process applied in the electroless nickel plating was adapted to obtain Ni-P powder, a basic conducting component of thick film. This process may be described by quoting a row of equations, the major ones being:

- catalytic decomposition of hypophosphite

$$
\begin{aligned}
& \mathrm{H}_{2} \mathrm{PO}_{2}^{-}+\mathrm{H}_{2} \mathrm{O} \rightarrow \mathrm{H}^{+}+\mathrm{HPO}_{3}^{2-}+2 \mathrm{H} \\
& - \text { reduction of nickel ions } \\
& \mathrm{Ni}^{2+}+2 \mathrm{H} \rightarrow \mathrm{Ni}+2 \mathrm{H}^{+} .
\end{aligned}
$$

Simultaneously the hypophosphite ions are reduced to elemental phosphorus P. At the beginning the presence of a catalytic agent, e.g. palladium, is required and then Ni-P itself acts as a catalyst. The product of nickel ion reduction by hypophosphite contains 7 to $16 \mathrm{wt} \% \mathrm{P}$, depending on reaction conditions, and this is why it is known as "Ni-P".

The aim of our work was to determine the properties of Ni-P as a conducting component of typical thick film compositions and eventually to find thick film composition containing Ni-P, which possess good resistance against oxidation.

In the present paper some results of these researches are given. Electrical and structural investigations were carried out successively on the compact Ni-P, thick films based on Ni-P with glass and on Ni-P mixed with glass and $\mathrm{B}_{2} \mathrm{O}_{3}$. Only this last material showed promising conducting properties.

\section{EXPERIMENTAL}

\subsection{Sample Preparation}

The Ni-P powders were obtained from a solution 
containing

$\begin{array}{lr}\mathrm{NiSO}_{4} \cdot 7 \mathrm{H}_{2} \mathrm{O} & 80 \mathrm{~g} / 1 \\ \mathrm{NaH}_{2} \mathrm{PO}_{2} \cdot \mathrm{H}_{2} \mathrm{O} & 24 \mathrm{~g} / 1 \\ \mathrm{CH}_{3} \mathrm{COONa} & 12 \mathrm{~g} / 1 \\ \mathrm{H}_{3} \mathrm{BO}_{3} & 8 \mathrm{~g} / 1 \\ \mathrm{NH}_{4} \mathrm{Cl} & 6 \mathrm{~g} / 1\end{array}$

The acidity of the solutions ranged from $\mathrm{pH} 3$ to $\mathrm{pH}$ 6.8. The reaction was initiated by heating the solutions to $95^{\circ} \mathrm{C}$ and adding a catalyst $\left(\mathrm{PdCl}_{2}\right.$ solution). The result of the reduction was a powder of Ni-P, of 2 to $10 \mu \mathrm{m}$ dimensions, often in a spongy form. The phosphorus content in the samples depend ed, as is well known, on the acidity of the solution (Figure 1).

The powders obtained were used to prepare the inks containing solid components in the ratios: 40 to $80 \mathrm{wt} \% \mathrm{Ni}-\mathrm{P}$ and 20 to $60 \mathrm{wt} \%$ glass or 40 to $80 \mathrm{wt} \%$ Ni-P, 15 to $55 \mathrm{wt} \%$ glass and 5 to $20 \mathrm{wt} \% \mathrm{~B}_{2} \mathrm{O}_{3}$. Most of the samples of Ni-P used contained $9 \mathrm{wt} \% \mathrm{P}$. The glass containing $80.4 \mathrm{wt} \%$ $\mathrm{PbO}, 10.4 \mathrm{wt} \% \mathrm{~B}_{2} \mathrm{O}_{3}$ and $9.2 \mathrm{wt} \% \mathrm{SiO}_{2}$ had a softening temperature below $600^{\circ} \mathrm{C}$. The medium glass grain diameters were close to about $5 \mu \mathrm{m}$ and did not exceed $15 \mu \mathrm{m}$. The reason why additional $\mathrm{B}_{2} \mathrm{O}_{3}$ was added to some mix tures will be explained later.

The inks also contained organic components: terpineol, igepal $\mathrm{CO}-880$ and ethylocellulose, that were wholly evaporated during the final heat treatment. The pastes were printed on 96 percent alumina substrates through 200 mesh stainless screens in simple patterns containing $1 \mathrm{~mm}$ wide meanders. These patterns were dried at $100^{\circ} \mathrm{C}$ for 10 minutes to a dry print thickness of 30 to $35 \mu \mathrm{m}$ and then were annealed in an air atmosphere at various temperatures, from $300^{\circ} \mathrm{C}$ to $800^{\circ} \mathrm{C}$, and various times, from 5 to 60 minutes. The films had thickness of 20 to $25 \mu \mathrm{m}$ after annealing.

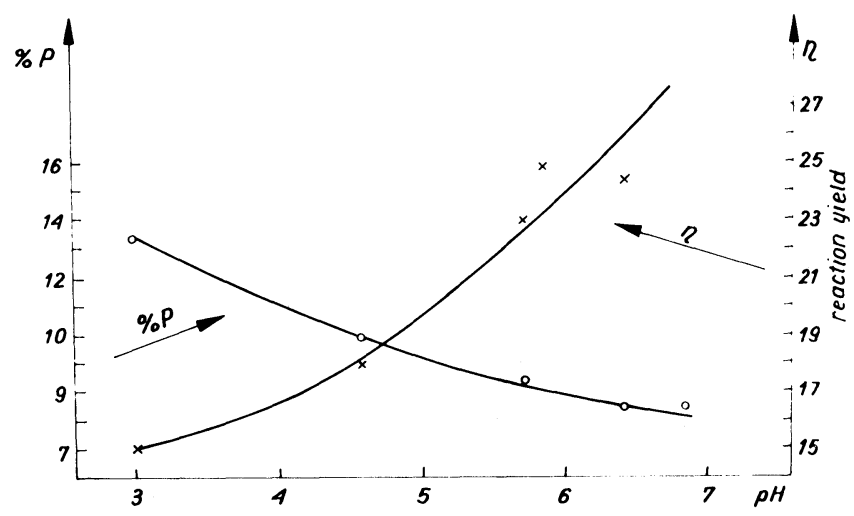

Figure 1 The phosphorus content $\% \mathbf{P}$ and reaction yield $\eta$ versus acidity of the solution used.
Compact samples of pure Ni-P were prepared by pressing Ni-P powder into pellets under a $4.5 \cdot 10^{6} \mathrm{~Pa}$ pressure.

\subsection{Methods of Sample Investigations}

Crystalline phases in Ni-P as well as in heated samples of the Ni-P-glass and Ni-P-glass- $\mathrm{B}_{2} \mathrm{O}_{3}$ systems were determined by standard X-ray diffractometer techniques. $\mathrm{CuK}_{\alpha}$ radiation was used; most of the diffraction patterns were registered in the angular range from $10^{\circ}$ to $42^{\circ}$. The techniques used made it possible to detect crystalline constituents if they exceeded $3 \mathrm{wt} \%$ of the total weight. The course of resistivity $\rho$ versus temperature $\mathrm{T}$ of the compact Ni-P samples terminated with silver paste was measured by the conventional dc method in a helium atmosphere at temperatures ranging from $20^{\circ} \mathrm{C}$ to $600^{\circ} \mathrm{C}$.

For electrical measurements Ni-P-glass- $\left(\mathrm{B}_{2} \mathrm{O}_{3}\right)$ films were terminated with $\mathrm{Du}$ Pont Silver Conductor 7713 paste. The sheet resistance $R_{\square}$ was measured by the conventional dc method at temperatures of $20^{\circ} \mathrm{C}$ and $120^{\circ} \mathrm{C}$ in an air atmosphere. A temperature coefficient of resistivity TCR was calculated from these results. The four-point probe method was also used and the same $R_{\square}$ and TCR values were obtained.

\section{RESULTS}

\subsection{Structural Constituents of Ni-P and Their Change Induced by Heating}

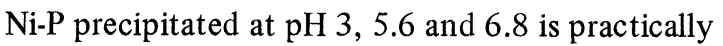
amorphous; sometimes one reflection corresponding to the spacing of lattice planes $d=2.03 \AA$ was observed. Initially amorphous Ni-P crystallizes after heating in a vacuum above $315^{\circ} \mathrm{C}$; when the samples

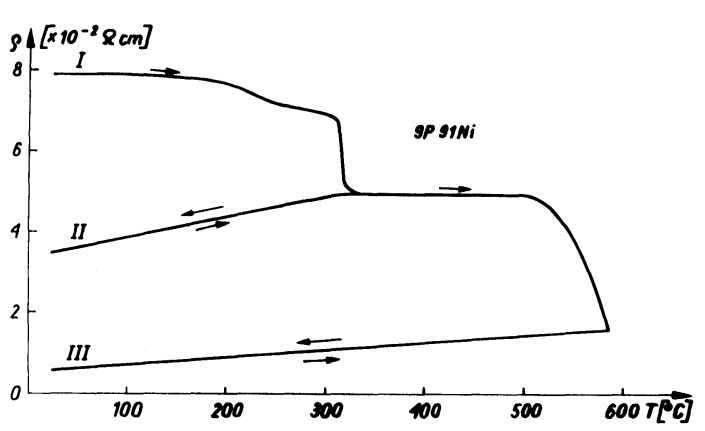

Figure 2 The resistivity $\rho$ of compact Ni-P containing $9 \mathrm{wt} \%$ P versus temperature $T$. The sample was heated in a helium atmosphere. The changes of resistivity in branch I are unreversible, in branches II and III - reversible. 
were heated at $350^{\circ}$ for $10 \mathrm{~min}$ the presence of nickel phosphide $\mathrm{Ni}_{3} \mathrm{P}$ and nickel Ni was observed.

The electrical resistivity $\rho$ taken through successive heat treatments of the compact Ni-P, 9 wt $\%$ of $\mathrm{P}$, sample is shown in Figure 2. The resistivity of the sample dropped sharply when the temperature reached $315^{\circ} \mathrm{C}$. This effect was assumed to be due to amorphous Ni-P crystallization which occurs at this temperature. The decrease in resistivity at temperatures higher than $500^{\circ} \mathrm{C}$ can be attributed to the sintering of the $\mathrm{Ni}_{3} \mathrm{P}$ and $\mathrm{Ni}$ powders. After reversing of the temperature course (cooling cycle - branch III in Figure 2) the resistivity is appreciably lower than the initial value. This can be explained by the fact that in this case the sample consisted of a sintered mixture of crystalline $\mathrm{Ni}_{3} \mathrm{P}+\mathrm{Ni}$ and not of amorphous phase Ni-P. The positive slope of branch III confirms the metallic character of the $\mathrm{Ni}_{3} \mathrm{P}-\mathrm{Ni}$ mixture.

The relative content of $\mathrm{Ni}_{3} \mathrm{P}$ and $\mathrm{Ni}$ in Ni-P after heating above $315^{\circ} \mathrm{C}$ clearly depends on the acidity value at which the Ni-P was precipitated; in the samples precipitated at $\mathrm{pH}=3$ the $\mathrm{Ni}_{3} \mathrm{P}$ content is highest. This $\mathrm{Ni}_{3} \mathrm{P}$ content diminishes gradually with the decrease in acidity of the nickel salt hypophosphite solution. The dependence of phosphorous content in the Ni-P on acidity has been shown in Figure 1. It can be clearly seen that samples precipitated at the higher acidity contain higher amounts of phosphorus, which explains the higher amount of $\mathrm{Ni}_{3} \mathrm{P}$ in the heated samples. The temperature of Ni-P crystallization is found to be virtually independent of the phosphorus content as can be recognized from the behaviour of resistivity $\rho$ against temperature $\mathrm{T}$; for all Ni-P samples investigated this temperature was equal to $315^{\circ} \pm 2^{\circ} \mathrm{C}$ (Figure 2).

The effect of heating in a vacuum on Ni-P phase constitution was similar to what had previously been observed in Ni-P thin layers. ${ }^{3}$ Ni-P samples heated in an air atmosphere also crystallize at about $315^{\circ} \mathrm{C}$; above about $400^{\circ} \mathrm{C}$ oxidation begins. The samples heated at $750^{\circ} \mathrm{C}$ for 10 min oxidized almost completely. In the oxidized material, nickel oxide $\mathrm{NiO}$ and nickel phosphates identified on the basis of the results presented by Sarver ${ }^{4}$ were detected among the other components.

\subsection{Structural Constituents of the Air Atmosphere Fired Ni-P-glass Samples}

$\mathrm{Ni}-\mathrm{P}$ in a mixture with $40 \mathrm{wt} \%$ glass behaves in quite a similar manner to the pure material; however, the oxidation resistance of $\mathrm{Ni}$ and $\mathrm{Ni}_{3} \mathrm{P}$, both observed

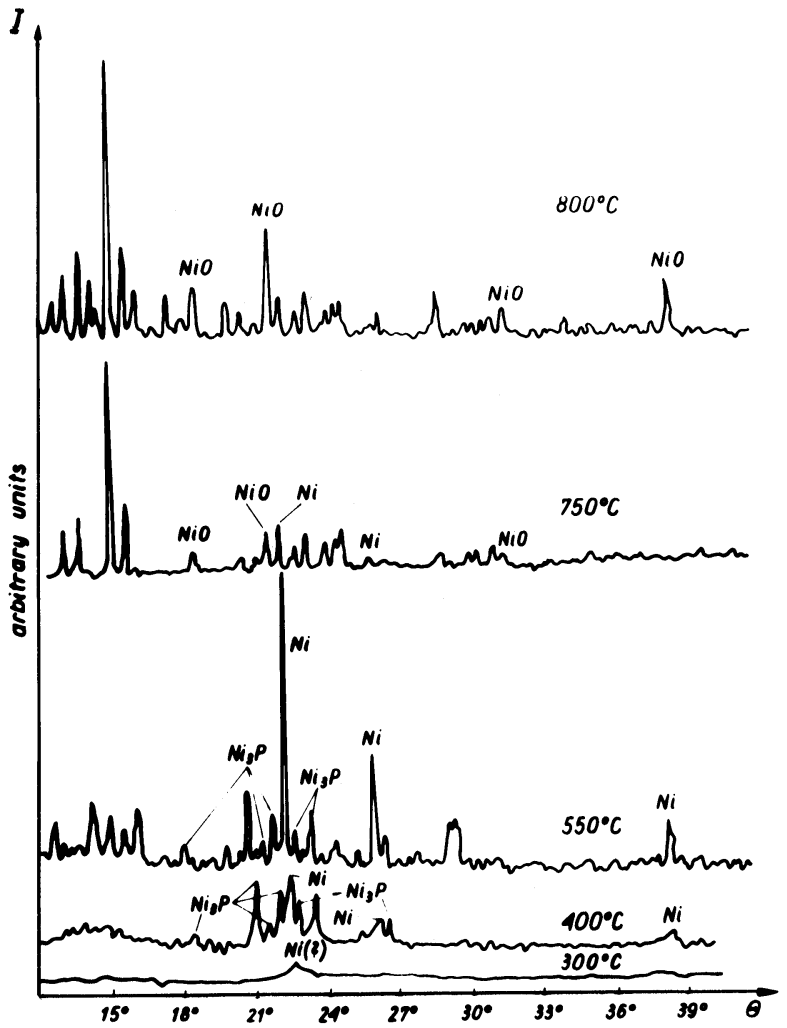

Figure 3 Diffraction patterns of Ni-P-glass system samples $(9 \mathrm{wt} \% \mathrm{P}$ in Ni-P) heated in an air atmosphere for $10 \mathrm{~min}$.

after preliminary heating above $315^{\circ} \mathrm{C}$, is slightly higher.

The relative content of $\mathrm{Ni}_{3} \mathrm{P}$ diminishes with an increase in temperature during heating in an air atmosphere beginning from about $450^{\circ} \mathrm{C}$; in the samples heated at $650^{\circ} \mathrm{C}$ for $10 \mathrm{~min} \mathrm{Ni}_{3} \mathrm{P}$ disappears completely. The process of $\mathrm{Ni}_{3} \mathrm{P}$ oxidation is accompanied by the appearance of numerous new X-ray diffraction lines (Figure 3); many of them correspond to some nickel phosphates.

The samples heated to $700^{\circ} \mathrm{C}$ revealed in the diffraction patterns the presence of $\mathrm{NiO}$; this $\mathrm{NiO}$ content increases with temperature increase, whereas the $\mathrm{Ni}$ content decreases. After heating at $800^{\circ} \mathrm{C}$ for $60 \mathrm{~min}$, Ni diffraction lines also disappear completely and numerous new diffraction lines are observed, a number of them belonging to the $\mathrm{NiO}$ phase. The remaining ones supposedly belong to the crystalline phases in glass-nickel (lead) phosphates systems. Lead, being a constituent of the glass, can also be transformed into phosphate. 
It is important to note, that these lines differ from the lines observed when pure Ni-P is heated under similar conditions. This fact supports the assumption that the crystalline phases of nickel (lead) phosphates-glass systems occur in air heated Ni-Pglass samples. In addition one cannot discount the possibility of the partial reduction of $\mathrm{PbO}$, contained in the glass, to lead $\mathrm{Pb}$, by $\mathrm{Ni}$ or $\mathrm{Ni}_{3} \mathrm{P}$, especially in the case of the samples heated at $600-700^{\circ} \mathrm{C}$.

The Ni-P-glass samples annealed above $600^{\circ} \mathrm{C}$ exhibit a very high sheet resistance $\left(R_{\square} \sim 10 \mathrm{M} \Omega\right)$. This corresponds to the disappearance of the conducting components from the original mix ture.

Thick film technology requires the stability of conductive components against oxidation during firing. At least a considerable part of such components ought to be unoxidized after the common heat treatment. To this end we attempted to modify the properties of the Ni-P-glass mixture by introducing special additives, which ought to decrease oxidation. The best results were obtained by adding to the Ni-P-glass mixture an amount of boric acid $\mathrm{H}_{3} \mathrm{BO}_{3}$, which decomposes to boric anhydride $\mathrm{B}_{2} \mathrm{O}_{3}$ when heated.

\subsection{Structural Constituents of the Air Atmosphere Fired Ni-P-glass- $\mathrm{B}_{2} \mathrm{O}_{3}$ Samples}

X-ray patterns of $55 \mathrm{wt} \% \mathrm{Ni-P}, 35 \mathrm{wt} \%$ glass, $10 \mathrm{wt} \%$ $\mathrm{B}_{2} \mathrm{O}_{3}$ samples, heated at different temperatures, are shown in Figure 4. Such patterns were typical for all samples of the Ni-P-glass- $\mathrm{B}_{2} \mathrm{O}_{3}$ system.

X-ray patterns of the samples heated below $300^{\circ} \mathrm{C}$ indicate only weak reflections belonging to $\mathrm{Ni}$ and $\mathrm{H}_{3} \mathrm{BO}_{3}$. At higher temperatures the Ni-P crystallizes. In the samples heated at $550-600^{\circ} \mathrm{C}$ the relative amount of $\mathrm{Ni}_{3} \mathrm{P}$ begins to diminish and in the samples heated at $700^{\circ} \mathrm{C}$ for $10 \mathrm{~min}$ this compound disappears completely. Above $550^{\circ} \mathrm{C}$ diffraction lines belonging to unidentified crystalline phases begin to occur. These phases disappear gradually when the samples are heated to $700-750^{\circ} \mathrm{C}$. $\mathrm{NiO}$ reflections were not present in all investigated samples heated to $800^{\circ} \mathrm{C}$. In these samples the $\mathrm{Ni}$ lines continue to be strong, whereas the $\mathrm{Ni}_{3} \mathrm{P}$ and unidentified reflections practically completely disappear (these unidentified reflections probably belong to crystalline phases in the glass- $\mathrm{B}_{2} \mathrm{O}_{3}$-nickel or lead phosphates systems). The results obtained suggest the usefulness of the above mentioned compositions in thick film applications. This was confirmed by the results of electrical measurements.

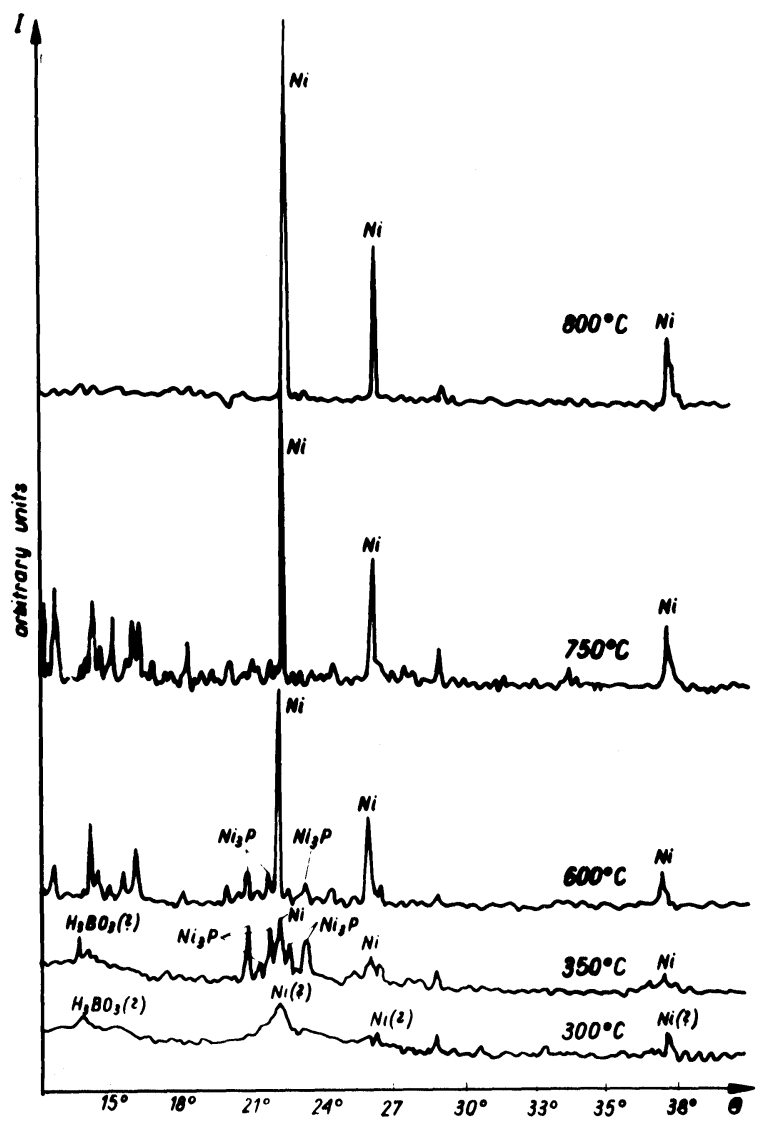

Figure 4 Diffraction patterns of Ni-P-glass- $\mathrm{B}_{2} \mathrm{O}_{3}$ system samples ( $9 \mathrm{wt} \% \mathrm{P}$ in Ni-P) heated in an air atmosphere for $10 \mathrm{~min}$.

\subsection{Electrical Properties of the Air Atmosphere Fired Ni-P-glass- $\mathrm{B}_{2} \mathrm{O}_{3}$ Samples}

Sheet resistances, $R_{\square}$, of $55 \mathrm{wt} \% \mathrm{Ni}-\mathrm{P}, 35 \mathrm{wt} \%$ glass, $10 \mathrm{wt} \% \mathrm{~B}_{2} \mathrm{O}_{3}$ films of about $20 \mu \mathrm{m}$ thickness, annealed at a temperature range $550^{\circ} \mathrm{C}$ to $800^{\circ} \mathrm{C}$ for 5 to $60 \mathrm{~min}$, are shown in Figures 5 and 6. Samples annealed below $550^{\circ} \mathrm{C}$ were not sintered and indicated a very high resistance $\left(R_{\square} \sim 10 \mathrm{M} \Omega\right)$.

The temperature of annealing as well as the phosphorus content had a considerable influence on the sheet resistance. Compositions containing more phosphorus displayed higher resistivity but the differences between samples of different phosphorus content decreased with a rise in temperature and disappeared when samples were annealed at about $800^{\circ} \mathrm{C}$.

Samples annealed at $800^{\circ} \mathrm{C}$ show the lowest resistance equal to $100 \mathrm{~m} \Omega /$ a after cooling to room 


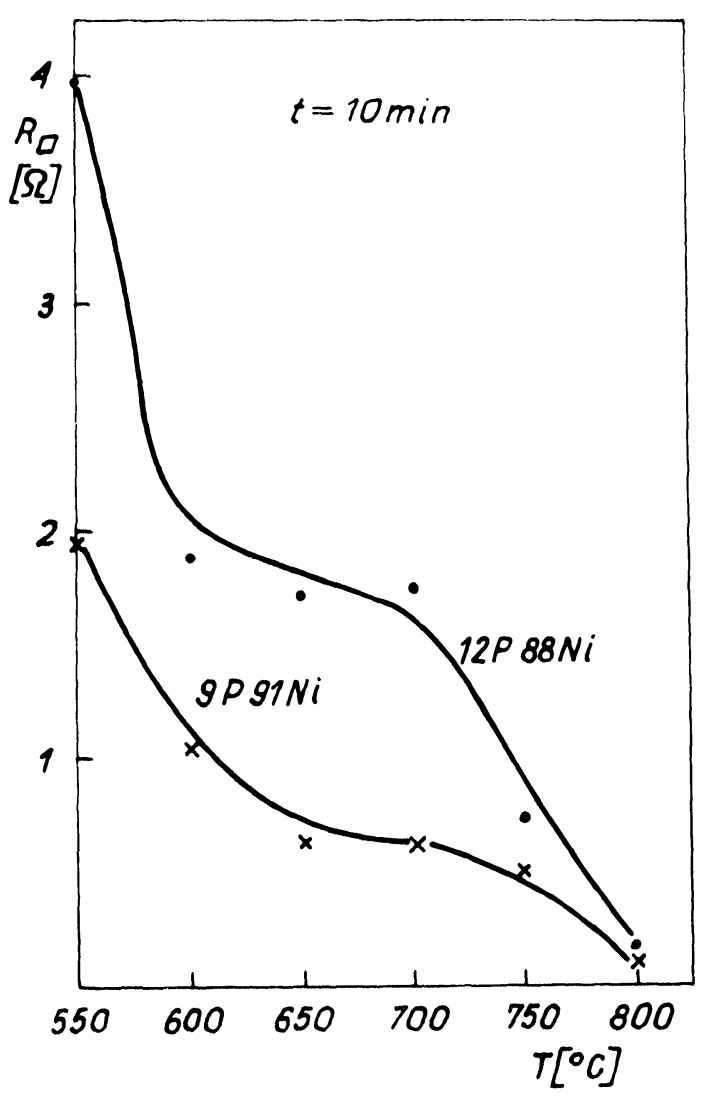

Figure 5 The sheet resistances $R_{\square}\left(20^{\circ} \mathrm{C}\right)$ of Ni-P-glass$\mathrm{B}_{2} \mathrm{O}_{3}$ system samples heated in an air atmosphere at different temperatures $T$. The film thickness $\sim 20 \mu \mathrm{m}$.

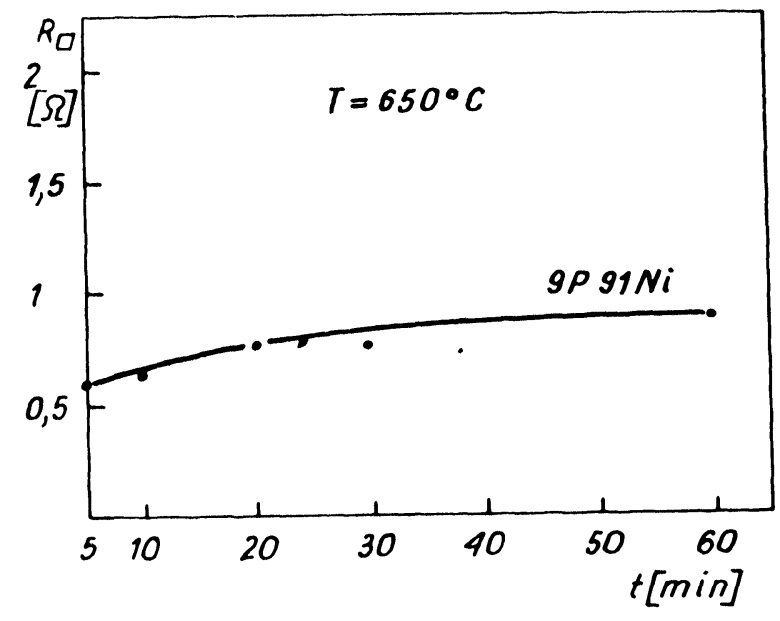

Figure 6 The sheet resistances $R_{\square}\left(20^{\circ} \mathrm{C}\right)$ of Ni-P-glass$\mathrm{B}_{2} \mathrm{O}_{3}$ system samples heated in an air atmosphere from 5 to $60 \mathrm{~min}$. The film thickness $\sim 20 \mu \mathrm{m}$. temperature and TCR equal to $+0.55 \% /{ }^{\circ} \mathrm{C}$. The heating time does not influence the sheet resistance appreciably (Figure 6). The compositions containing $45-80 \mathrm{wt} \%$ of Ni-P in mix ture with the glass and $\mathrm{B}_{2} \mathrm{O}_{3}$ also exhibit conductor properties after annealing at $800^{\circ} \mathrm{C}$, whereas the compositions with a Ni-P content beyond the range mentioned above demonstrated non-conducting characteristic $\left(R_{\square}>1 \mathrm{M} \Omega\right)$.

\section{DISCUSSION}

In Ni-P-glass samples (without $\mathrm{B}_{2} \mathrm{O}_{3}$ ) annealed in an air atmosphere, oxidation is noticed starting at about $450^{\circ} \mathrm{C}$. X-ray diffraction patterns of the samples heated to temperatures above $650^{\circ} \mathrm{C}$ display a number of NiO lines. Their intensity increases as the temperature of annealing is increased.

In the samples annealed at $800^{\circ} \mathrm{C}$ all of the $\mathrm{Ni}$ (contained originally in the form of $\mathrm{Ni}_{3} \mathrm{P}$ as well as $\mathrm{Ni}$ ) is completely oxidized. The electrical measurements carried out on this material prove that it is not technically useful.

The presence of boric oxide $\mathrm{B}_{2} \mathrm{O}_{3}$ modifies and protects Ni-P-glass compositions against oxidation during heat treatment in an air atmosphere. The disappearance of $\mathrm{Ni}_{3} \mathrm{P}$ now occurs at higher temperatures and the nickel oxide is not observed even in samples heated up to $800^{\circ} \mathrm{C}$.

The antioxidation influence of $\mathrm{B}_{2} \mathrm{O}_{3}$ when added to a Ni-P-glass mix ture (or more precisely, to $\mathrm{Ni}_{-} \mathrm{Ni}_{3} \mathrm{P}$ glass mix ture at above $315^{\circ} \mathrm{C}$ ) is difficult to explain. The isolation of $\mathrm{Ni}$ and $\mathrm{Ni}_{3} \mathrm{P}$ grains against air admission by the molten $\mathrm{B}_{2} \mathrm{O}_{3}$ (m.p. $450^{\circ} \mathrm{C}$ ), as well as lowering of the softening point of glass can be of some importance.

The different amount of $\mathrm{P}$ in Ni-P related to the Ni-P precipitation conditions $(\mathrm{pH})$ influences the oxidation properties of Ni-P-glass- $\mathrm{B}_{2} \mathrm{O}_{3}$ mix tures to some extent. In the samples precipitated at higher acidity, that is containing a higher percentage of phosphorus, the concentration of $\mathrm{Ni}_{3} \mathrm{P}$ in the mix ture after crystallization is also higher (Figure 7). Such samples indicate the presence of $\mathrm{Ni}_{3} \mathrm{P}$ after heating to $700^{\circ} \mathrm{C}$; however, after heating to higher temperatures $\left(800^{\circ} \mathrm{C}\right) \mathrm{Ni}_{3} \mathrm{P}$ disappears completely.

The Ni-P-glass- $\mathrm{B}_{2} \mathrm{O}_{3}$ samples heated in the air at $800^{\circ} \mathrm{C}$ display an X-ray diffraction pattern in which only the lines belonging to nickel $\mathrm{Ni}$ are present, any additional lines have disappeared almost completely (Figure 4). This disappearance is probably caused by the dissolution of the phosphates crystal- 


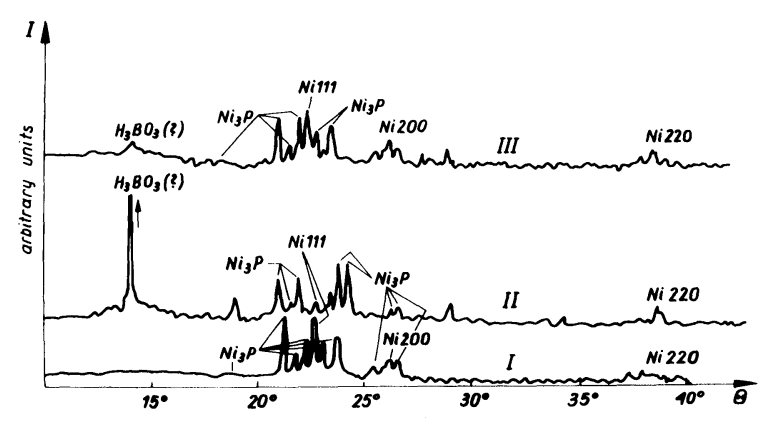

Figure 7 Diffraction patterns of Ni-P-glass (I) and Ni-Pglass- $\mathrm{B}_{2} \mathrm{O}_{3}$ (II, III) system samples heated in an air atmosphere at $350^{\circ} \mathrm{C}$ for $10 \mathrm{~min}$. Ni-P contains $9 \mathrm{wt} \% \mathrm{P}$ (I, III) and $13 \mathrm{wt} \% \mathrm{P}$ (II).

line phases, from which these additional reflections may originate, in the molten glass.

Summarizing, the addition of about $10 \mathrm{wt} \%$ of $\mathrm{B}_{2} \mathrm{O}_{3}$, preferably in the form of $\mathrm{H}_{3} \mathrm{BO}_{3}$, to the Ni-P-glass mix tures, stabilizes them against oxidation during air heating at temperatures up to $800^{\circ} \mathrm{C}$.

Electrical measurements confirm the metallic conductivity of Ni-P-glass- $\mathrm{B}_{2} \mathrm{O}_{3}$ composed material; there is a high positive TCR like that of metallic Ni. Such conducting properties are typical for Ni-Pglass- $\mathrm{B}_{2} \mathrm{O}_{3}$ mix tures containing 45 to $80 \mathrm{wt} \%$ of $\mathrm{Ni}-\mathrm{P}$ in the original composition. However, below this Ni-P content the situation changes considerably. A sharp transition from conducting $\left(R_{\square}=0.1 \Omega\right)$ to nonconducting $\left(R_{\square}=10 \mathrm{M} \Omega\right)$ properties is observed. Such a transition can be expected in the simple dispersed system of conducting particles in an insulating matrix. ${ }^{5}$ The resistivity of the resultant material increases suddenly as the concentration of conductive particles decreases beyond a certain critical value. At this concentration infinite chains of conductive particles effectively cease to exist. The chains of connected metal particles act like conducting filaments and are responsible for the conducting properties of the whole material. In our situation both $\mathrm{Ni}$ and $\mathrm{Ni}_{3} \mathrm{P}$ particles can be treated as conducting components from the electric point of view. Conducting chains of metallic particles are formed in selected Ni-P-glass- $\mathrm{B}_{2} \mathrm{O}_{3}$ compositions when the concentration of the metallic particles exceeds a critical value, in our case approximately $45 \mathrm{wt} \%$.

According to the results obtained and in view of the adapted model it can be said that it is rather difficult to obtain a thick film resistive material based on Ni-P with a high enough sheet resistance. However, the conductor properties are satisfactory and taking into account the comparatively low cost of Ni-P, the compositions described can be hopefully recommended for conductor thick layers.

\section{ACKNOWLEDGEMENTS}

We would like to thank Professor B. Licznerski, Dr A. Bochenek and Dr L. Golonka for the inspiring discussion as well as Dr. J. Markowski for his help in electrical measurements.

\section{REFERENCES}

1. M. Schlesinger and J. P. Marton, "Electrical and optical properties of Ni-P films", J. Appl. Phys. 40, 507 (1969).

2. P. I. Cote, "Electrical resistivity of amorphous phosphorus alloys", Sol, State Commun. 18, 1311 (1976).

3. S. T. Pai and J. P. Marton "Annealing effects on the structure and resistivity of Ni-P films", J. Appl. Phys. 43, 2, 282 (1972).

4. I. F. Sarver, "Compound formation and phase equilibrium relationships in the system CoO- $\mathrm{P}_{2} \mathrm{O}_{5}$ and $\mathrm{NiO}-\mathrm{P}_{2} \mathrm{O}_{5}$ ", Trans. \& J. Br. Ceram. Soc. (GB) 65, 191 (1966).

5. B. Walton, "Principles of thick film materials formulation" Radio and Electronic Eng., (GB) 45, 139 (1975). 

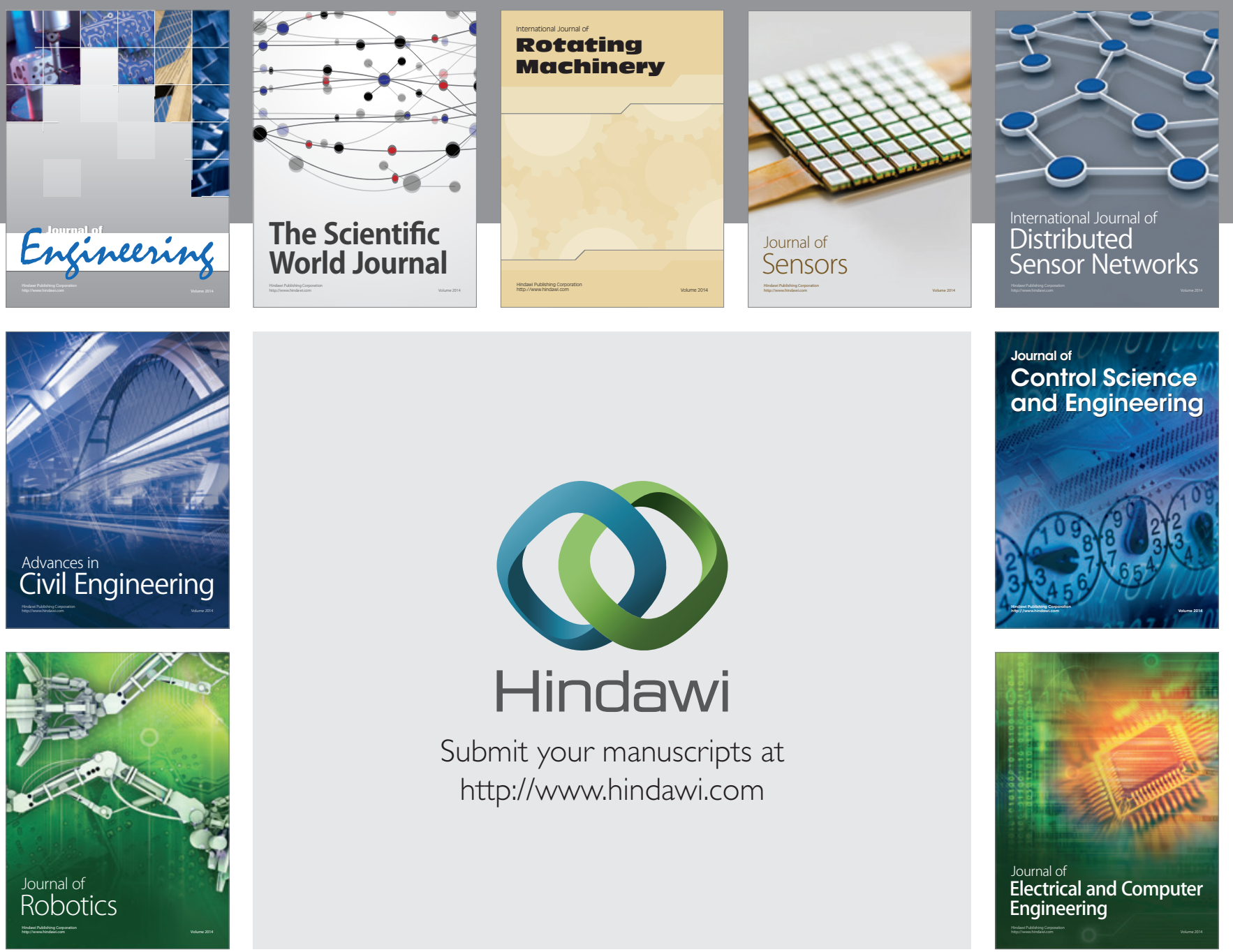

Submit your manuscripts at

http://www.hindawi.com
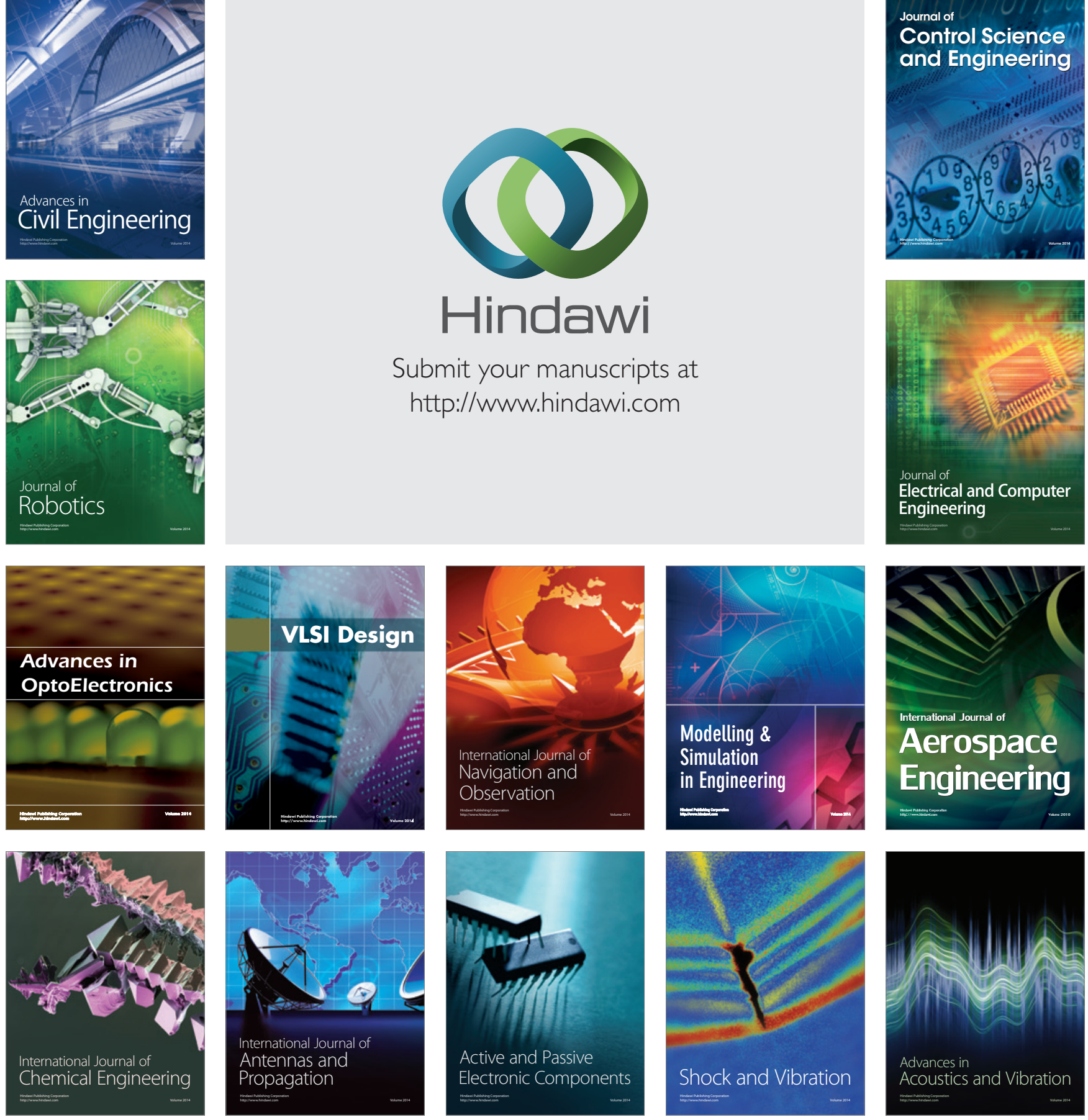